\title{
Fluorescent protein vectors for pancreatic islet cell identification in live-cell imaging
}

\author{
Hongyan Shuai $^{1} \cdot$ Yunjian Xu $^{1} \cdot$ Qian Yu $^{1} \cdot$ Erik Gylfe $^{1} \cdot$ Anders Tengholm $^{1}$ (D)
}

Received: 4 June 2016 / Revised: 2 August 2016 / Accepted: 4 August 2016 /Published online: 18 August 2016

(C) The Author(s) 2016. This article is published with open access at Springerlink.com

\begin{abstract}
The islets of Langerhans contain different types of endocrine cells, which are crucial for glucose homeostasis. $\beta$ and $\alpha$-cells that release insulin and glucagon, respectively, are most abundant, whereas somatostatin-producing $\delta$-cells and particularly pancreatic polypeptide-releasing PP-cells are more scarce. Studies of islet cell function are hampered by difficulties to identify the different cell types, especially in live-cell imaging experiments when immunostaining is unsuitable. The aim of the present study was to create a set of vectors for fluorescent protein expression with cell-typespecific promoters and evaluate their applicability in functional islet imaging. We constructed six adenoviral vectors for expression of red and green fluorescent proteins controlled by the insulin, preproglucagon, somatostatin, or pancreatic polypeptide promoters. After transduction of mouse and human islets or dispersed islet cells, a majority of the fluorescent cells also immunostained for the appropriate hormone. Recordings of the sub-plasma membrane $\mathrm{Ca}^{2+}$ and cAMP concentrations with a fluorescent indicator and a protein biosensor, respectively, showed that labeled cells respond to glucose and other modulators of secretion and revealed a striking variability in $\mathrm{Ca}^{2+}$ signaling among $\alpha$-cells. The measurements allowed comparison of the phase relationship of $\mathrm{Ca}^{2+}$ oscillations between different types of cells within intact islets. We conclude that the fluorescent protein vectors allow easy identification of specific islet cell types and can be used in live-cell imaging together with organic dyes and genetically encoded biosensors. This approach will facilitate studies of
\end{abstract}

Anders Tengholm

Anders.Tengholm@mcb.uu.se

1 Department of Medical Cell Biology, Uppsala University, Biomedical Centre, Box 571, SE-751 23 Uppsala, Sweden normal islet physiology and help to clarify molecular defects and disturbed cell interactions in diabetic islets.

Keywords Islets $\cdot \alpha$-cell $\cdot \beta$-cell $\cdot \delta$-cell $\cdot$ PP-cell $\cdot$ Insulin $\cdot$ Glucagon $\cdot$ Somatostatin $\cdot$ Pancreatic polypeptide $\cdot \mathrm{Ca}^{2+}$. cAMP

\section{Introduction}

The pancreatic islets of Langerhans are key regulators of glucose homeostasis. They contain four major types of endocrine cells: $\alpha-, \beta-, \delta-$, and PP-cells, secreting glucagon, insulin, somatostatin, and pancreatic polypeptide (PP), respectively $[36,45]$. The $\beta$ cells are most abundant and constitute $60-80 \%$ of the endocrine cells in islets from mice and $\sim 50 \%$ in human islets. $\alpha$-cells make up $\sim 20 \%$ in mouse and $\sim 40 \%$ in man, while $\delta$ - and PP-cells are more scarce constituting $<10$ and $<1 \%$ of the islet cells, respectively. There is also a small fraction of $\varepsilon$-cells secreting ghrelin [54]. Insulin decreases blood glucose levels and insufficient insulin release from the $\beta$-cells causes most forms of diabetes mellitus. Glucagon, on the contrary, increases blood glucose. Diabetic patients often show exaggerated glucagon secretion that contributes to hyperglycemia, but also a reduced glucagon response to hypoglycemia, which may become fatal due to the brain's strong glucose dependence $[14,50]$. All major islet hormones are released in a pulsatile manner [15, 21, 24], which promotes hormone sensitivity in the target cells [37, 42]. Indeed, insulin and glucagon pulsatility is typically disturbed in early stages of diabetes $[27$, $34,40]$ but the molecular mechanisms that underlie the dysregulated secretion are unclear. The physiological relevance of islet somatostatin and PP is not well understood. PP was recently found to suppress glucagon secretion by direct effects on $\alpha$-cells [2] and somatostatin inhibits both insulin and glucagon secretion [18]. Somatostatin pulsatility is in phase with that of insulin [20, 
21], and somatostatin's stronger inhibitory effect on glucagon than on insulin secretion [43] may help to shape pulsatile glucagon secretion in opposite phase [29].

Studies of cell functions and interactions in situ within pancreatic islets depend on unambiguous cell identification, which is far from trivial. Immunostaining of dispersed islet cells has successfully been used to identify all major islet cell types after studying their physiological $\mathrm{Ca}^{2+}$ responses $[6,19$, $30,31]$, but the process is time-consuming and cells may be lost during fixation and staining. The immunostaining approach is even more difficult when applied to cells within pancreatic islets, since it requires that the cells remain in exact position within the high magnification view field throughout the identification procedure. Electrophysiological techniques have also been used to identify $\alpha$-, $\beta$-, and $\delta$-cells $[3,8,26]$ but this approach is difficult to apply to more than one cell at a time. The difference in expression of adrenergic receptors can also be utilized to discriminate $\alpha$ - and $\beta$-cells. $\alpha$-cells mainly express $\alpha 1$ - and $\beta$-receptors [44], which trigger elevations of the cytoplasmic $\mathrm{Ca}^{2+}$ and cAMP concentrations in response to adrenaline $[49,52]$. In contrast, $\beta$-cells express mainly $\alpha 2$ receptors [44], and adrenaline therefore lowers cAMP [49] and suppresses $\mathrm{Ca}^{2+}$ signaling [52]. Similarly, the $\mathrm{Ca}^{2+}$ response to glutamate has been used for identifying $\alpha$ - and $\beta$ cells $[9,29]$ based on different expression of ionotropic glutamate receptors of AMPA/kainate type. These pharmacological tools depend on recordings of intracellular $\mathrm{Ca}^{2+}$ and cAMP. Moreover, they do not allow unambiguous separation of $\alpha$ - and $\beta$-cells from the less common $\delta$ - and PP-cells.

Cell identification by genetic labeling is an attractive alternative, where tissue-specific promoters are used to control expression of fluorescent markers. This approach has been applied to generate transgenic mice with selective expression of fluorescent proteins in $\alpha$-, $\beta$-, and $\delta$-cells under the promoters for preproglucagon, insulin, and somatostatin, respectively $[1,17,38]$. A drawback with this approach is that it is restricted to cell identification in specific transgenic mouse strains and not practically applicable to other species.

In the present study, we tested cell-type-specific promoterdriven expression of fluorescent proteins for identification of mouse and human islet cells in live-cell fluorescence microscopy applications. To ascertain sufficient expression levels, we constructed adenoviral vectors based on the Tet-On $3 \mathrm{G}$ conditional expression system $[56,32]$. The preproglucagon promoter (Pppg), the rat insulin 2 promoter (Rip2), the somatostatin promoter (Psst), and the pancreatic polypeptide promoter (Pppy) were used to drive expression of the reverse tetracycline transactivator protein (rtTA), while the genes for the fluorescent proteins mCherry or enhanced green fluorescent protein (GFP) were placed downstream of the tetracycline response element. We demonstrate that this method results in mCherry or GFP expression in $\beta-, \alpha-, \delta$-, or PP-cells with a high degree of specificity and that appropriately labeled cells in mouse and human islets were amenable for on-line recordings of the sub-plasma membrane $\mathrm{Ca}^{2+}$ and cAMP concentrations $\left(\left[\mathrm{Ca}^{2+}\right]_{\mathrm{pm}}\right.$ and $\left.[\mathrm{cAMP}]_{\mathrm{pm}}\right)$.

\section{Materials and methods}

\section{Isolation of cell-type-specific promoters}

cDNA for Rip2 was a kind gift from Dr. Lena Stenson-Holst, Lund University. Pppg, Psst, and Pppy were isolated from genomic DNA using PCR. DNA was purified from MIN6 $\beta$-cells with PureLink ${ }^{\circledR}$ Genomic DNA Mini Kit (ThermoFisher Scientific, Waltham, MA, USA) and used as PCR template. Primer design was based on published promoter sequence data [11, 55, 22, 33, 25, 46, 47]. An Xhol restriction site (underlined) was added to the sense primer ( $5^{\prime}$-ATCG TACTCGAGGACACTCGCAATCATAAAGAGCAATC-3' for Pppg; 5'-TATACTCGAGCAACCACTCCAAGTGGAG3' for Rip2; 5'-ATATATCTCGAGAGCCTAGAGGCAGA GCAAGCGCTG-3' for Psst; 5'-CATGAGG $\underline{\text { CTCG }}$ AGTCGGAACTAGCCACTGGTTTTG-3' for Pppy) and an AscI site to the antisense primer (5'-AAATGGCGCGCC TGAGCTGCGAACAGgTGTAG-3' for Pppg; 5'-ATTT AAATGGCGCGCCTTACTGAATCCCCAC-3' for Rip2; 5' - A ATTAAGGCGCGCCGGAGACCGTGGAGA GCTCCATAGCG-3' for Psst; 5'-GACATATGGCGCGCC TGTGCTGAGCTAGTGAGTG-3' for Pppy). Standard PCR reactions were performed with PfuTurbo high-fidelity DNA polymerase (Agilent Technoliges, Santa Clara, CA, USA). The 1659-bp Pppg, 684-bp Rip2, 1986-bp Psst, and 1420-bp Pppy PCR products were purified by gel extraction, ligated into the pCR ${ }^{\circledR} I I-T O P O$ vector (Thermo-Fisher Scientific, Waltham, MA, USA) and verified by sequencing (Eurofins Genomics, Ebergberg, Germany). Pppg, Rip2, Psst, and Pppy were subsequently released by digestion with XhoI and AscI.

\section{Construction of Tet-On 3G plasmids with cell-type-specific promoters}

To avoid the potential problem that the promoters are too weak to drive expression of sufficient amounts of fluorescent protein for cell identification, we took advantage of the Tet-On conditional expression system. In this approach, a cell-typespecific promoter could drive expression of a small amount of rtTA, which is sufficient to strongly activate the tetracycline response element (TRE) and downstream genes in the presence of doxycycline.

To insert the cell-type-specific promoters in plasmids encoding rtTA, the pBR322-E3-Tet-On-rev plasmid [4] (kind gift from Prof Göran Akusjärvi, Uppsala University) was cleaved with $\mathrm{XhoI}$ and $\mathrm{XbaI}$ to release the cytomegalovirus 
promoter with a $5^{\prime} \mathrm{UTR}$ extension of the rtTA gene. This CMV-5'UTR fragment was subsequently ligated into an inhouse made cloning vector denoted $\mathrm{pCFH}$ to get $\mathrm{pCFH}-\mathrm{CMV}$ 5'UTR. After cleavage with XhoI and Eco53kI, the CMV promoter was released and replaced by the Rip2 promoter carrying a AscI site at the $3^{\prime}$ end. Eventually, the Rip2-5' UTR fragment was cut out with XhoI and XbaI and ligated into the cleaved pBR322-E3-rtTA- $\triangle \mathrm{CMV}$ fragment to get pBR322-E3-Rip2-rtTA, which now included the cell-typespecific promoter instead of the original CMV promoter. All other promoter constructs were completed by replacing Rip2 with Pppg, Psst, or Pppy, respectively, after XhoI-AscI double digestion. Finally, rtTA was replaced with Tet-On $3 \mathrm{G}$ transactivator $[32,56]$ by isolating the Tet-On $3 \mathrm{G}$ from pCMV-Tet3G plasmid (Clontech, USA) after digestion with XhaI and HpaI.

\section{Construction of plasmids for TRE-regulated mCherry and EGFP expression}

In the next step, the pTRE3G-IRES plasmid (Clontech, Palo Alto, CA, USA) was cleaved with BglII and BamHI, to release the IRES component and insert either of the fluorescent proteins mCherry or GFP.

\section{Virus recombination and amplification}

The four Tet-On $3 \mathrm{G}$ plasmids with cell-type-specific promoters and the two TRE plasmids with fluorescent protein were sent to Vector Biolabs (Philadelphia, PA, USA) for recombination and initial virus production. The final vector constructions are shown in Fig. 1. High titer virus stocks were created in-house in HEK 293 cells grown in $15 \mathrm{~cm}$ Petri dishes to about $50 \%$ confluence. The cells were washed once with DMEM containing $2 \%(v / v)$ fetal bovine serum (FBS) and infected with a titer of 2-5 MOI (multiplicity of infection) virus in this medium for $1 \mathrm{~h}$. The infection mixture was subsequently removed and the cells were cultured in fresh DMEM containing $10 \%(v / v)$ FBS for 2 or 3 days at $37{ }^{\circ} \mathrm{C}$ in a humidified atmosphere with $5 \% \mathrm{CO}_{2}$. When about $40 \%$ of the cells had started to detach from the bottom of the Petri dish, all cells were harvested with a cell scraper, centrifuged for $7 \mathrm{~min}$ at $1800 \mathrm{~g}$ and resuspended in $2 \mathrm{ml} 0.1 \mathrm{M}$ Tris-HCl, $\mathrm{pH}$ 8.0. Sodium deoxycholate $(200 \mu \mathrm{l}, 5 \% \mathrm{w} / \mathrm{v})$ was added and the cells were incubated on ice for $30 \mathrm{~min}$. The virus was then released from the cells by sonication on ice three times for $10 \mathrm{~s}$ with 1-min intervals. The sonication solution was mixed with Tris- $\mathrm{HCl}$ and saturated $\mathrm{CsCl}$ and added to a 12.6-ml Quickseal tube (Beckman Instruments, Fullerton, CA, USA) and centrifuged for $16-20 \mathrm{~h}$ at $115,000 \mathrm{~g}, 4{ }^{\circ} \mathrm{C}$, with a Beckman $80 \mathrm{Ti}$ rotor. After centrifugation, the virus band was sucked out with a syringe and dialyzed for $4 \mathrm{~h}$ at $4{ }^{\circ} \mathrm{C}$ in phosphate buffered saline supplemented with $0.9 \mathrm{mM}$
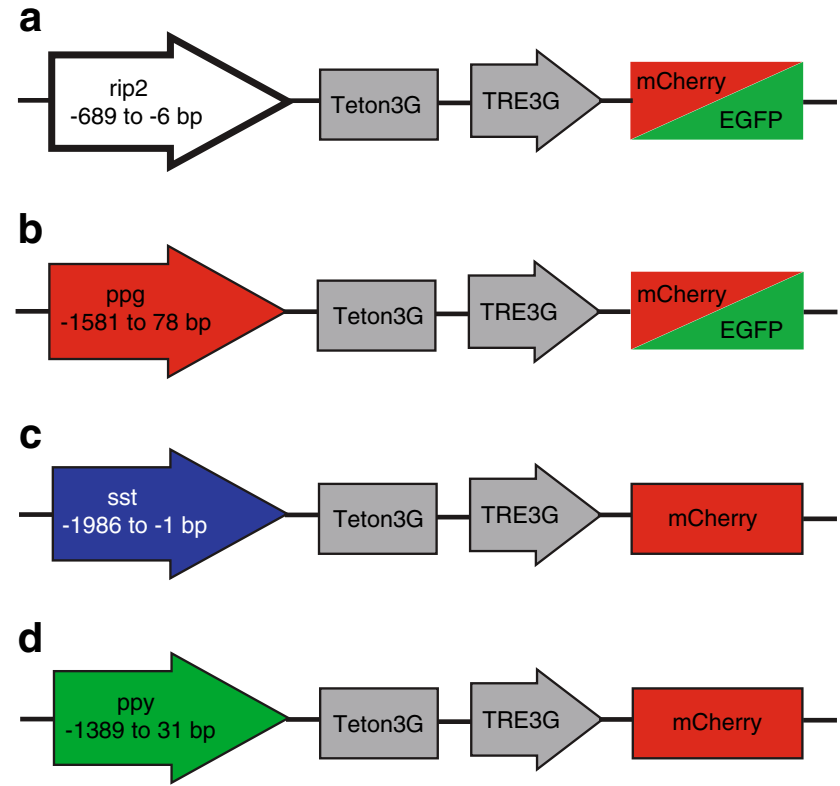

Fig. 1 Adenoviral gene constructs for conditional, islet cell-type-specific expression of fluorescent proteins. The indicated fragments of the rat insulin 2 promoter (rip2), preproglucagon promoter (ppg), somatostatin promoter (sst), and the pancreatic polypeptide promoter (ppy) were inserted upstream of a Tet-On $3 \mathrm{G}$ element expressing the reverse tetracycline transactivator. In the presence of doxycycline, this gene product activates the tetracycline response element (TRE3G) and the associated promoter that drives expression of the fluorescent proteins mCherry or green fluorescent protein (GFP)

$\mathrm{CaCl}_{2}$ and $0.5 \mathrm{mM} \mathrm{MgCl}_{2}$ as well as $10 \%(v / v)$ glycerol. After dialysis, the virus suspension was aliquoted and stored at $-80{ }^{\circ} \mathrm{C}$.

\section{Islet isolation, culture, and transduction}

All procedures for animal handling and islet isolation were approved by the Uppsala animal ethics committee. Islets of Langerhans were isolated from C57B16J female mice as described previously [53]. After isolation, the islets were cultured for 1 to 2 days in RPMI-1640 medium containing $5.5 \mathrm{mM}$ glucose, $10 \%(\mathrm{v} / \mathrm{v})$ fetal calf serum, $100 \mathrm{U} / \mathrm{mL}$ penicillin, and $100 \mu \mathrm{g} / \mathrm{mL}$ streptomycin at $37{ }^{\circ} \mathrm{C}$ in a $5 \% \mathrm{CO}_{2}$ humidified air atmosphere. Human islets were obtained from four normoglycemic cadaveric organ donors (two males, two females aged 57-65 years) via the Nordic Network for Clinical Islet Transplantation in Uppsala. All experiments with human islets were approved by the Uppsala human ethics committee. The isolated islets were cultured up to 7 days at $37{ }^{\circ} \mathrm{C}$ in an atmosphere of $5 \% \mathrm{CO}_{2}$ in CMRL 1066 culture medium containing $5.5 \mathrm{mM}$ glucose, $100 \mathrm{U} / \mathrm{mL}$ penicillin and $100 \mu \mathrm{g} / \mathrm{mL}$ streptomycin, $2 \mathrm{mM}$ glutamine, and $10 \%$ FBS. For some experiments, the islets were dispersed into single cells and small clusters by transferring them to $2 \mathrm{~mL}$ cell dissociation buffer (Thermo Fisher Scientific) containing $10 \%(v / v)$ trypsin-EDTA $(0.05 \%$, Life Technologies $)$, 
followed by pipetting up and down 20-30 times until all islets were disintegrated. The trypsin digestion was interrupted by addition of $8 \mathrm{ml}$ serum-containing RPMI-1640 medium, followed by centrifugation for $5 \mathrm{~min}$ at $160 \mathrm{~g}$ and resuspension of the cells in islet culture medium. The cell suspension was subsequently added onto poly-lysine-coated $25-\mathrm{mm}$ coverslips and cultured overnight. The islets or cells were infected with adenovirus by 3 to $4 \mathrm{~h}$ exposure to a concentration of 105 fluorescence forming units (FFU)/islet [49], followed by addition of regular medium with $4 \mu \mathrm{M}$ doxycycline and further culture for 16 to $20 \mathrm{~h}$ before use.

\section{Immunostaining}

The infected islets were washed three times with PBS, fixed with $4 \%(w / v)$ paraformaldehyde for $10 \mathrm{~min}$ in room temperature and permeabilized with $0.2 \%(v / v)$ TrionX-100 for $10 \mathrm{~min}$ on ice. The reaction was blocked by adding PBS containing $5 \%$ FBS in room temperature. After 30 min incubation, the primary antibody (polyclonal rabbit anti-insulin or polyclonal rabbit anti-glucagon from Invitrogen, Carlsbad, CA; polyclonal rabbit anti-somatostatin from Dako, Stockholm, Sweden; polyclonal goat anti-pancreatic polypeptide from Bio-Techne, Abingdon, UK) was added (1:200) for $2 \mathrm{~h}$, followed by thorough rinsing with PBS. The secondary antibody, Alexa Fluor® 488 goat anti-rabbit IgG (Invitrogen, Carlsbad, CA) or Alexa Fluor® 488-AffiniPure F(ab')2 fraction donkey anti-goat $\operatorname{IgG}(\mathrm{H}+\mathrm{L})$ (Jackson ImmunoResearch Europe Ltd., Suffolk, UK), was then applied (1:200) for $1 \mathrm{~h}$ in darkness. After rinsing with PBS, the islets or cells were used for confocal microscopy imaging.

\section{Confocal microscopy}

The islets or cells were imaged in a spinning-disk confocal system (Yokogawa CSU-10, Andor Technology, Belfast, Northern Ireland) attached to an Eclipse TE2000 microscope (Nikon, Kawasaki, Japan) equipped with a $60 \times, 1.40-\mathrm{NA}$ objective (Nikon, Kawasaki, Japan). Diode-pumped solid-state lasers (Cobolt, Stockholm, Sweden) were used for excitation of mCherry $(561 \mathrm{~nm})$ and GFP or Alexa Fluor ${ }^{\circledR} 488(491 \mathrm{~nm})$. Fluorescence was selected with interference filters (520 with $35 \mathrm{~nm}$ half-bandwidth for GFP and Alexa Fluor ${ }^{\circledR}$ 488, and $586 / 20 \mathrm{~nm}$ for mCherry) and images were acquired with a back-illuminated EMCCD camera (DU888, Andor Technology) under MetaFluor software control (Molecular Devices Corp., Downington, PA). The confocal imaging experiments were performed at room temperature.

\section{Imaging of $[\mathrm{CAMP}]_{\mathrm{pm}}$ and $\left[\mathrm{Ca}^{2+}\right]_{\mathrm{pm}}$}

For imaging of $[\mathrm{cAMP}]_{\mathrm{pm}}$, the islets were transduced with a cyan and yellow fluorescent protein (CFP and YFP)-based
cAMP translocation biosensor [13] together with the fluorescent labeling vector and cultured over night. The islets or cells were then pre-incubated for $30 \mathrm{~min}$ at $37^{\circ} \mathrm{C}$ in experimental buffer containing $125 \mathrm{mM} \mathrm{NaCl}, 4.8 \mathrm{mM} \mathrm{KCl}, 1.3 \mathrm{mM}$ $\mathrm{CaCl}_{2}, 1.2 \mathrm{mM} \mathrm{MgCl}_{2}$, and $25 \mathrm{mM}$ HEPES (pH 7.40 set with $\mathrm{NaOH})$ prior to imaging. For $\left[\mathrm{Ca}^{2+}\right]_{\mathrm{pm}}$ recordings, the islets were loaded with $1.3 \mu \mathrm{M}$ of the $\mathrm{Ca}^{2+}$ indicator Fluo-4 during the pre-incubation period. After incubation, the islets were attached to poly-lysine-coated 25 -mm coverslips and the coverslips with cells or islets were mounted in an open $50-\mu \mathrm{l}$ chamber and superfused with experimental buffer at a rate of $0.3 \mathrm{ml} / \mathrm{min}$. The chamber was attached to the stage of an objective-based total internal reflection fluorescence (TIRF) microscopy system consisting of an Eclipse Ti microscope (Nikon) with a $60 \times, 1.45$-NA objective and a TIRF illuminator (Nikon) [49]. The chamber and superfusion medium was thermostated to $37^{\circ} \mathrm{C}$. The $457,491,515$, and $561 \mathrm{~nm}$ lines of diode-pumped solid-state lasers (Cobolt) were used to excite CFP, Fluo-4, YFP, and mCherry, respectively. Fluorescence was detected with a back-illuminated EMCCD camera (DU897, Andor Technology) controlled by MetaFluor. Emission wavelengths were selected with filters $[485 \mathrm{~nm} / 25 \mathrm{~nm}$ halfbandwidth for CFP, 527/27 nm for Fluo-4, 560/40 nm for YFP (Semrock Rochester, NY) and $620 \mathrm{~nm}$ long-pass for mCherry (Melles Griot, Didam, The Netherlands)] mounted in a filter wheel (Sutter Instruments). For time-lapse recordings, images or image pairs were acquired every $5 \mathrm{~s}$ with a shutter (Sutter Instruments) blocking the light between image captures. Image analysis was performed with MetaFluor. $\mathrm{Ca}^{2+}$ indicator fluorescence intensities under the plasma membrane were expressed as changes in relation to initial fluorescence intensity $\mathrm{F}_{0}$ after subtraction of background $\left(\mathrm{F} / \mathrm{F}_{0}\right)$. [cAMP $]_{\mathrm{pm}}$ was expressed as the ratio of CFP over YFP fluorescence after subtraction of background.

\section{Statistical analysis}

Chi-square analysis with Yates correction was used to compare the proportion of cells that immunostained for a hormone in relation those with hormone promoter-controlled fluorescent protein expression.

\section{Results and discussion}

\section{Fluorescence labeling of $\beta$-cells in mouse and human pancreatic islets}

Isolated mouse islets were transduced with adenovirus expressing GFP or the red fluorescent protein mCherry conditionally controlled by the Rip 2 promoter and the Tet-On $3 \mathrm{G}$ system and subsequently imaged with confocal microscopy. Fluorescence was absent in islets that had not been exposed to 
doxycycline (not shown), indicating that there is minimal leak expression with this conditional vector system. Islets treated overnight with $4 \mu \mathrm{M}$ doxycycline showed bright GFP (not shown) or mCherry fluorescence (Fig. 2a). The specificity of the targeting strategy was evaluated using the mCherryexpressing vectors. Transduced islets immunostained for insulin showed cells with red (mCherry) and green (insulin) fluorescence (Fig. 2a). As indicated by the Venn plot, $97 \%$ of the fluorescent cells stained for insulin, $28 \%$ were mCherry positive and $26 \%$ displayed both labels. When islets with induced Rip2-mCherry expression were instead immunostained for glucagon only $6 \%$ of the fluorescent cells showed both labels (Fig. 2b). mCherry expression is apparently a good predictor of $\beta$-cell identity since $90 \%$ of the red cells stained for insulin and only $7 \%$ for glucagon. When Rip2-mCherry expression was induced in dispersed islet cells that were then immunostained for insulin, 32 fluorescent cells all stained for insulin and $78 \%$ (25 cells) were also mCherry positive (not shown). The much higher proportion of mCherry label in dispersed fluorescent cells as compared to those within islets (78 vs $28 \% ; P<0.001)$ is probably due to restricted virus access to the islet interior where most $\beta$-cells are located [45]. The reason for the expression of Rip2-mCherry in a small number of glucagon-positive islet cells and why no such mistargeting was found in dispersed cells is unclear. Human $\beta$-cells in intact islets could be identified by the same approach, since $95 \%$ of mCherry expressing cells also stained for insulin (Fig. 2c), and the corresponding fraction was $93 \%$ among dispersed human islet cells (28 of 30 cells, not shown).

\section{Fluorescence labeling of $\alpha$-cells in mouse and human pancreatic islets}

Mouse islets transduced with adenovirus containing Pppg and mCherry or GFP showed bright red or green fluorescent cells. As with Rip2, evaluation of targeting specificity was made with the mCherry-expressing virus. In transduced mouse islets immunostained for glucagon, $52 \%$ of the fluorescent cells were mCherry positive (Fig. 3a). This proportion is higher than for the $\beta$-cells ( $28 \%, P<0.001)$, probably because $\alpha$ cells are more easily transduced with virus in being located in the periphery of rodent islets [45]. mCherry expression was a good predictor of $\alpha$-cell phenotype since $73 \%$ of the cells within rodent islets also stained for glucagon, and the corresponding fraction was $100 \%$ among dispersed islet cells (all of 64 cells, not shown). After instead staining for insulin $15 \%$ of the mCherry expressing cells within islets were positive (Fig. 3b). This mismatch was higher than for $\beta$-cells ( $7 \%$, $P<0.05)$ and it is unclear whether it reflects incomplete specificity of the relatively short Pppg sequence and/or a small population of cells with ambiguous identity. It has been increasingly recognized that islet cells show plasticity with transdifferentiation between $\alpha$ - and $\beta$-cells under certain conditions [48, 51, 7]. The Pppg adenovirus readily transduced human islets and following glucagon immunostaining, $41 \%$ of all fluorescent cells were mCherry positive. This proportion tended to be lower than in mouse islets (52\%, $P=0.068)$, which is expected since human $\alpha$-cells are not preferentially located in the islet periphery [45]. Among the mCherryexpressing cells within islets, $88 \%$ were verified as $\alpha$-cells
Fig. 2 Insulin promotercontrolled expression of mCherry in mouse and human islet cells. Confocal microscopy images of Rip2-controlled mCherry expression and insulin or glucagon immunostaining in mouse and human islets. a Rip2mCherry expressing and insulin positive cells in a mouse islet. $\mathbf{b}$ Rip2-mCherry expressing and glucagon positive cells in a mouse islet. c Rip2-mCherry expressing and insulin positive cells in a human islet. Scale bars, $10 \mu \mathrm{m}$. The Venn diagrams on the right show the total number of cells with hormone staining (green), mCherry expression (red), and both (yellow)
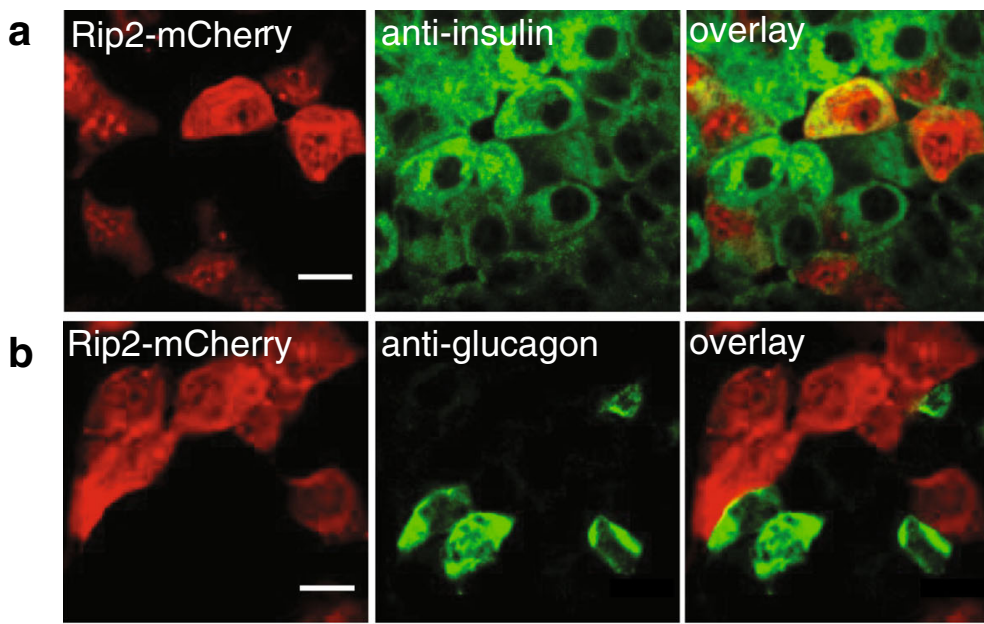

C

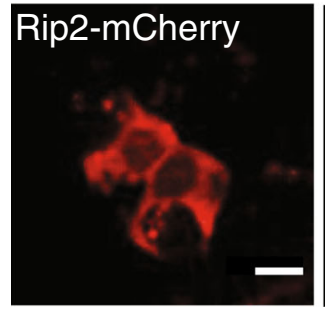

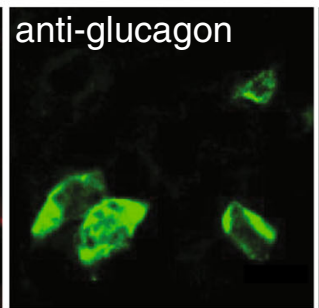

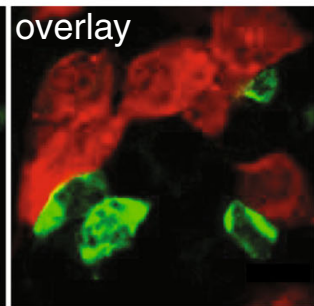

anti-insulin

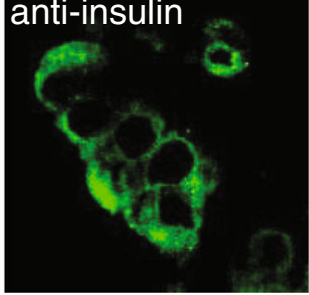

overlay
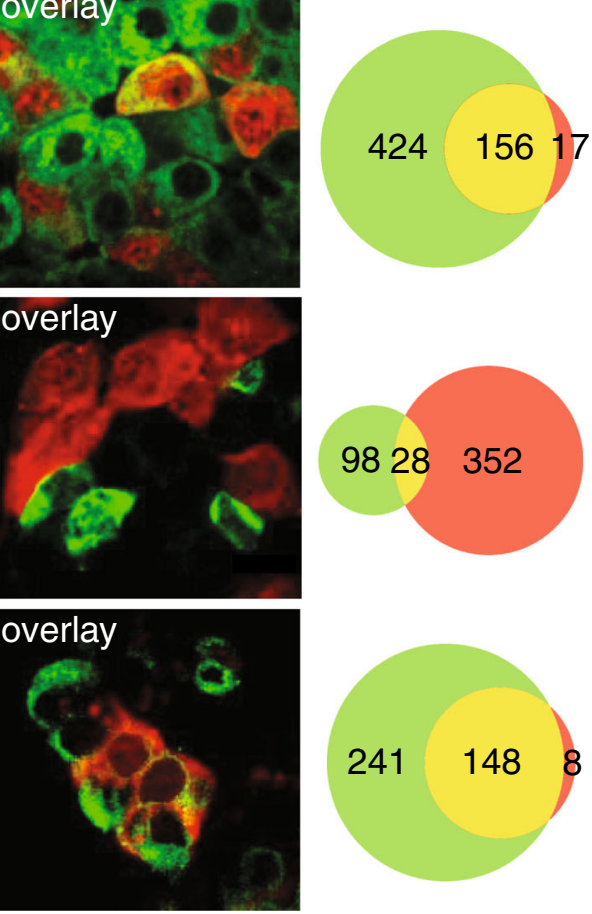
Fig. 3 Glucagon promotercontrolled expression of mCherry in mouse and human islet cells. Confocal microscopy images of Pppg-controlled mCherry expression and insulin or glucagon immunostaining in mouse and human islet cells. a Pppg-mCherry expressing and glucagon positive cells in a mouse islet. b Pppg-mCherry expressing and insulin positive cells in a mouse islet. c Pppg-mCherry expressing and glucagon positive cells in a human islet. Scale bars, $10 \mu \mathrm{m}$. The Venn diagrams on the right show the total number of cells with hormone staining (green), mCherry expression (red), and both (yellow)
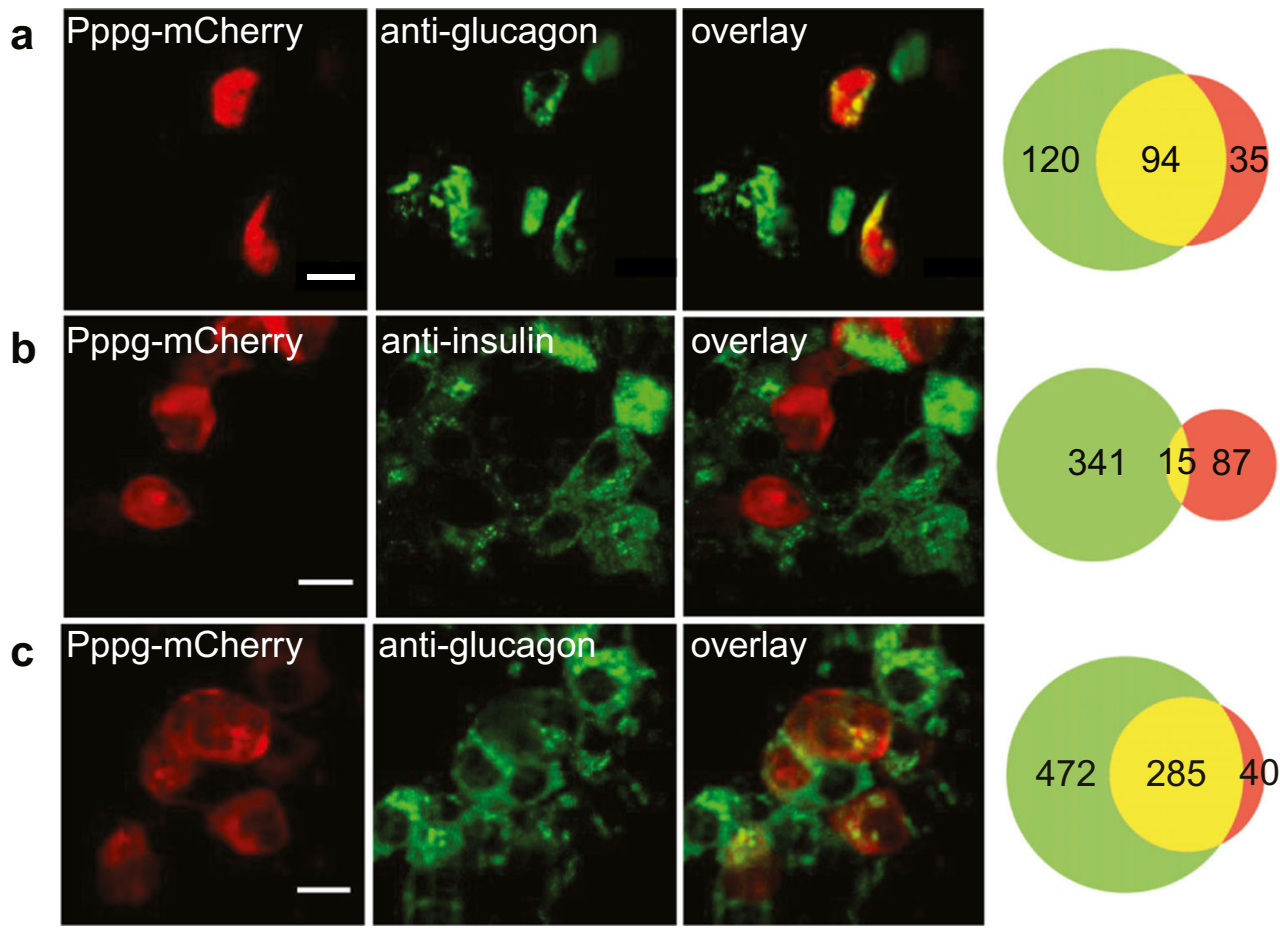

by glucagon immunostaining (Fig. 3c), and the corresponding fraction was $85 \%$ for dispersed human islet cells (47 of 55 cells, not shown).

\section{Fluorescence labeling of mouse and human $\delta$ - and PP-cells}

The adenovirus with Psst and Pppy transduced relatively few cells in mouse and human islets. To effectively find these cells, we transduced and immunostained dispersed mouse and human islet cells. The Psst-mCherry expression overlapped with positive anti-somatostatin staining in $86-87 \%$ in both species, verifying their identity as $\delta$-cells (Fig. $4 a, b$ ). Labeling with Pppy-mCherry was observed both in mouse (Fig. 4c) and human (Fig. 4d) PP-cells, whose identity was verified by positive PP-immunostaining in $88 \%$ of the mouse and $93 \%$ of the human cells.

\section{TIRF recordings of $\left[\mathrm{Ca}^{2+}\right]_{\mathrm{pm}}$ in islet cells identified by cell-type-specific fluorescent protein expression}

We next tested whether the cell identification strategy could be used in live-cell imaging applications. Islets transduced with the respective cell-type-specific vector expressing mCherry were loaded with the green fluorescent $\mathrm{Ca}^{2+}$ indicator fluo-4, which does not show spectral overlap with the red label. The islets were imaged with a total internal reflection fluorescence microscope, which excites a small volume within $<100 \mathrm{~nm}$ of the plasma membrane of the cells in contact with the coverslip. Although this technique does not enable analysis of cells located deeper in the islet, it is advantageous in allowing recordings from small cells with weak fluorescence without contamination from cells located in a different focal plane.

We stimulated the islets with various concentrations of glucose and tested the responses to the $\mathrm{K}_{\text {ATP }}$ channel opener diazoxide and the neurotransmitters glutamate and adrenaline, which have been used to discriminate between the different islet cell types [9, 29, 49, 52]. Mouse $\beta$-cells identified by their Rip2-controlled mCherry fluorescence showed low and stable $\left[\mathrm{Ca}^{2+}\right]_{\mathrm{pm}}$ in the presence of $3 \mathrm{mM}$ glucose (Fig. 5a). Increase of the glucose concentration to $7 \mathrm{mM}$ resulted in lowering of $\left[\mathrm{Ca}^{2+}\right]_{\mathrm{pm}}$, known to reflect stimulated uptake of $\mathrm{Ca}^{2+}$ into the endoplasmic reticulum, followed after a few minutes delay by an increase reflecting voltage-dependent $\mathrm{Ca}^{2+}$ influx [10]. Further elevation of glucose to $11 \mathrm{mM}$ resulted again in transient lowering followed by rise of $\left[\mathrm{Ca}^{2+}\right]_{\mathrm{pm}}$ with typical slow oscillations that underlie pulsatile insulin secretion. Application of the hyperpolarizing agent diazoxide $(250 \mu \mathrm{M})$ interrupted the voltage-dependent $\mathrm{Ca}^{2+}$ influx and $\left[\mathrm{Ca}^{2+}\right]_{\mathrm{pm}}$ levels returned to baseline. Under these conditions, the $\beta$-cells did not respond to $1 \mathrm{mM}$ glutamate or $10 \mu \mathrm{M}$ adrenaline (Fig. 5a). The observed response pattern is characteristic of $\beta$-cells and there was not much variability between different cells. From these observations, we conclude that the viral vector and fluorescent protein expression do not interfere with $\beta$-cell function. 
Fig. 4 Somatostatin and PP promoter-controlled expression of mCherry in mouse and human islet cells. Confocal microscopy images of Psst- and Pppycontrolled mCherry expression and somatostatin and PP immunostaining in dispersed mouse and human islet cells. a, b Psst-mCherry expressing and somatostatin positive mouse (a) and human (b) islet cells. c, $\mathbf{d}$ Pppy-mCherry expressing and PP positive mouse (c) and human (d) islet cells. Scale bars, $10 \mu \mathrm{m}$. The Venn diagrams on the right show the total number of cells with hormone staining (green), mCherry expression (red), and both (yellow)

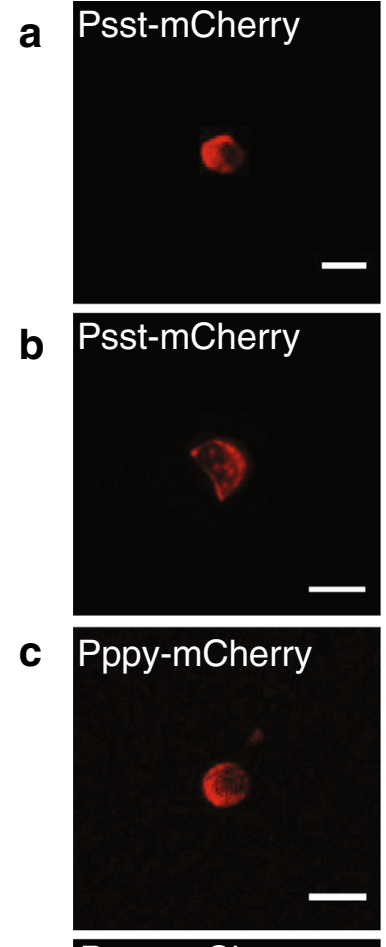

d

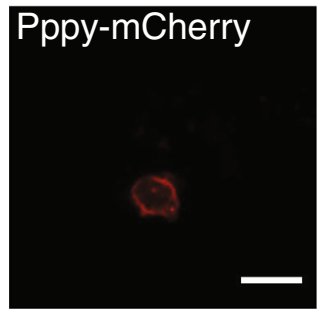

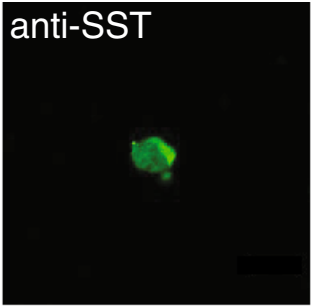
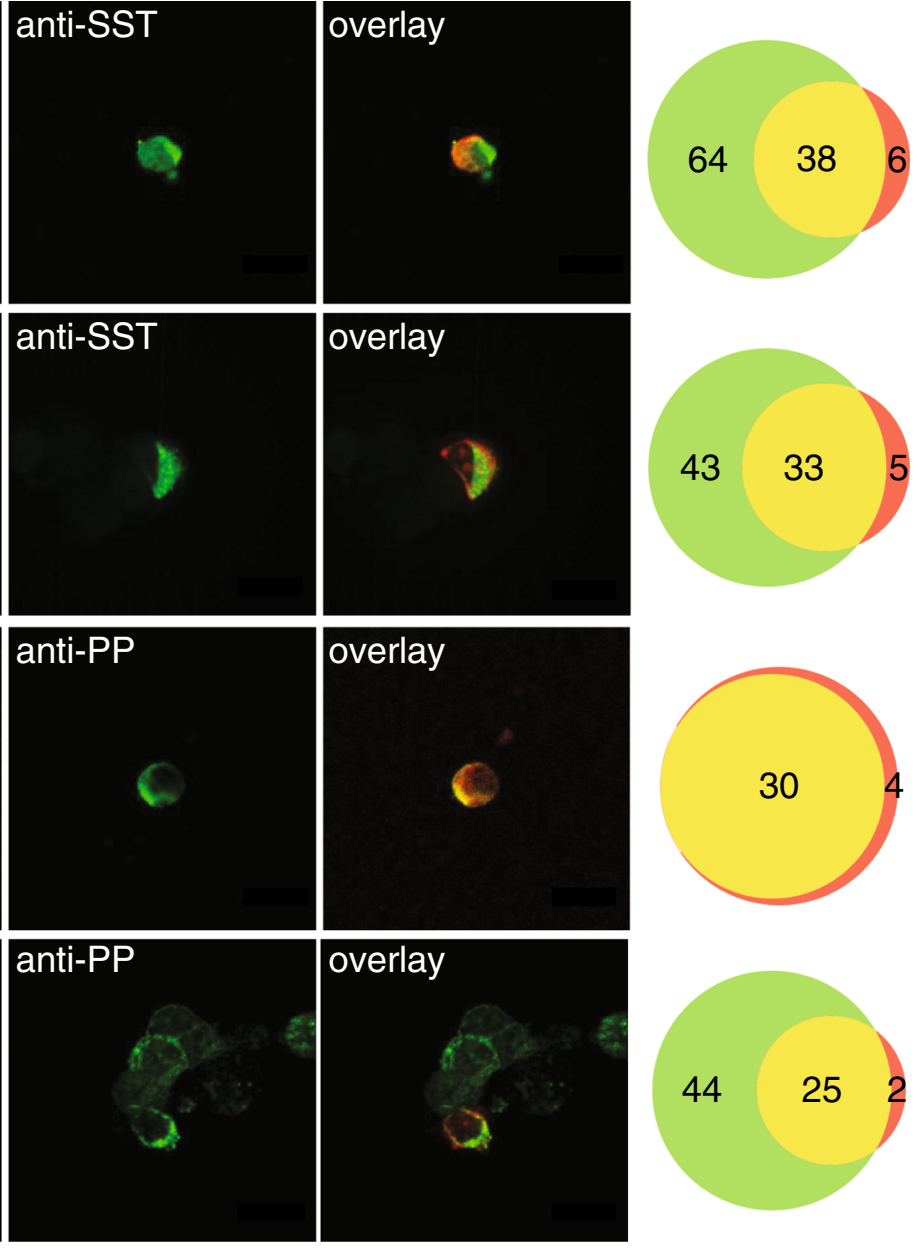

\section{Variability of $\left[\mathrm{Ca}^{2+}\right]_{\mathrm{pm}}$ responses to glucose in $\alpha$-cells}

Recordings from $\alpha$-cells identified by Pppg-mCherry fluorescence were largely consistent with a previous study of $\alpha$-cell $\left[\mathrm{Ca}^{2+}\right]_{\mathrm{pm}}$ signaling [29]. Accordingly, most cells showed irregular brief $\left[\mathrm{Ca}^{2+}\right]_{\mathrm{pm}}$ oscillations in the presence of $3 \mathrm{mM}$ glucose, and increases of the glucose concentration to 7 and $11 \mathrm{mM}$ did not induce sustained suppression of $\left[\mathrm{Ca}^{2+}\right]_{\mathrm{pm}}$ signaling (Fig. 5b) but there was sometimes a transient interruption of $\left[\mathrm{Ca}^{2+}\right]_{\mathrm{pm}}$ oscillations or somewhat lower amplitude of the oscillations at $11 \mathrm{mM}$ compared to $3 \mathrm{mM}$ glucose. Seven out of $10 \alpha$-cells showed no or weak response to $K_{\text {ATP }}$ channel activation with diazoxide (Fig. 5b), supporting the view that this channel may not be required for glucose regulation of glucagon secretion [14]. In accordance with previous observations [29], the mouse $\alpha$-cells responded to $1 \mathrm{mM}$ glutamate with a distinct, stable $\left[\mathrm{Ca}^{2+}\right]_{\mathrm{pm}}$ elevation (Fig. 5b). Also, $10 \mu \mathrm{M}$ adrenaline induced $\left[\mathrm{Ca}^{2+}\right]_{\mathrm{pm}}$ elevation but this response was usually weaker and/or more transient than that to glutamate. mCherry-negative cells from the same islets showed $\beta$-cell-like responses with low and stable $\left[\mathrm{Ca}^{2+}\right]_{\mathrm{pm}}$ at $3 \mathrm{mM}$ glucose, a distinct increase of $\left[\mathrm{Ca}^{2+}\right]_{\mathrm{pm}}$ at $11 \mathrm{mM}$, which was reversed by diazoxide, and no responses to glutamate or adrenaline (Fig. 5b). Our genetic labeling strategy thus mostly identifies $\alpha$ - and $\beta$-cells with characteristic $\left[\mathrm{Ca}^{2+}\right]_{\mathrm{pm}}$ responses to low and high glucose concentrations as well as to glutamate and adrenaline.

A few mCherry-positive $\alpha$-cells showed somewhat more $\beta$ cell-like response with absence of prominent $\left[\mathrm{Ca}^{2+}\right]_{\mathrm{pm}}$ signaling activity at $3 \mathrm{mM}$ glucose and distinct $\left[\mathrm{Ca}^{2+}\right]_{\mathrm{pm}}$ increases after elevation of glucose to $7 \mathrm{mM}$ (Fig. $5 \mathrm{c}$ ). The two types of $\alpha$-cell responses were sometimes observed in different cells within the same islet. In the cell shown in Fig. 5c, the glucose-induced $\left[\mathrm{Ca}^{2+}\right]_{\mathrm{pm}}$ elevation was reversed by diazoxide, like in $\beta$-cells. One may speculate that this type of response represents "mislabeled" cells with Pppg-controlled mCherry expression and positive immunostaining for insulin. However, the cell shown in Fig. $5 \mathrm{c}$ responded to glutamate and adrenaline like a typical $\alpha$ cell. Simultaneous recording from an adjacent mCherry negative cell exhibited the typical $\beta$-cell behavior with glucose-induced $\left[\mathrm{Ca}^{2+}\right]_{\mathrm{pm}}$ increases and lack of glutamate and adrenaline responses. The results indicate possible presence of subpopulations of $\alpha$-cells that respond differently to glucose. Although glucose is generally an inhibitor of glucagon release, secretion from purified rodent $\alpha$-cells is paradoxically stimulated by the sugar $[23,28,35]$. One possibility is that purification by 

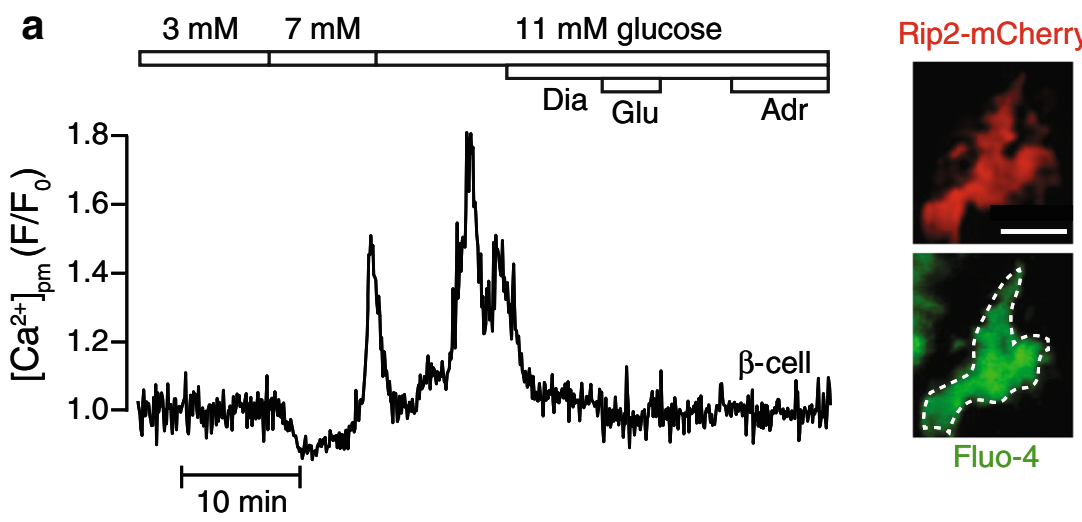

Fluo-4

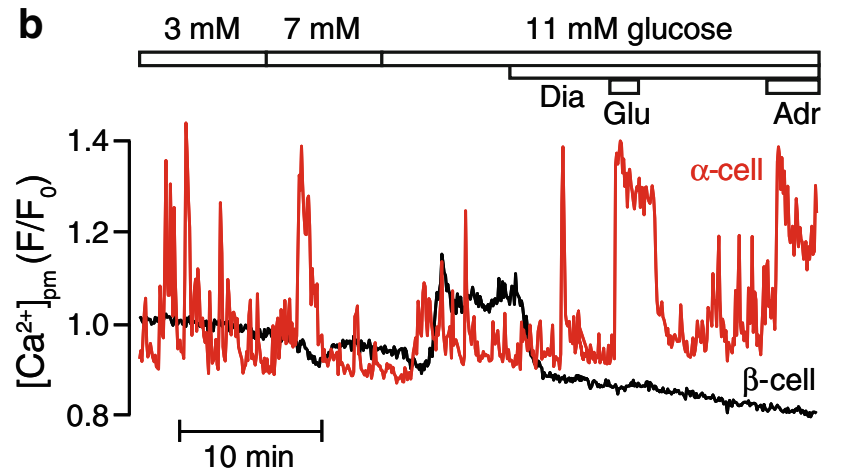

Pppg-mCherry

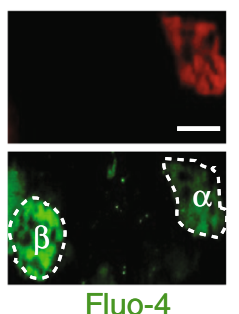

Fluo-4

C

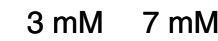

$11 \mathrm{mM}$ glucose

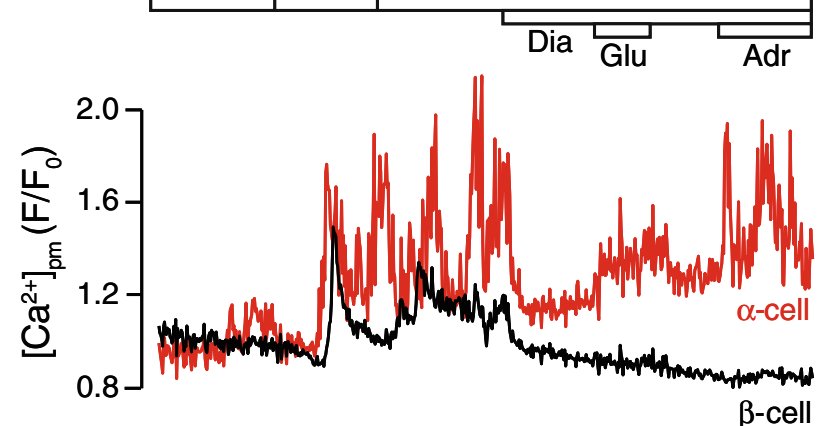

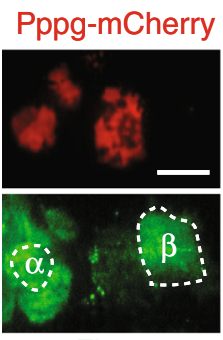

Fluo-4
Fig. 5 Recordings of sub-plasma membrane $\mathrm{Ca}^{2+}$ concentration in $\beta$ and $\alpha$-cells identified by cell-type-specific promoter-controlled expression of mCherry. TIRF microscopy recordings of $\left[\mathrm{Ca}^{2+}\right]_{\mathrm{pm}}$ in cells within intact mouse islets loaded with the $\mathrm{Ca}^{2+}$ indicator Fluo-4 and exposed to 3-11 mM glucose, $250 \mu \mathrm{M}$ diazoxide (Diaz), $1 \mathrm{mM}$ glutamate (Glu), and $10 \mu \mathrm{M}$ adrenaline (Adr). a $\left[\mathrm{Ca}^{2+}\right]_{\mathrm{pm}}$ recording from a $\beta$-cell identified by Rip2-mCherry expression. Increase of the glucose concentration from 3 to $7 \mathrm{mM}$ induces elevation of $\left[\mathrm{Ca}^{2+}\right]_{\mathrm{pm}}$, which is reversed by diazoxide. Glutamate and adrenaline are without effect on basal $\left[\mathrm{Ca}^{2+}\right]_{\mathrm{pm}}$. Representative of 18 cells from five islets. b $\left[\mathrm{Ca}^{2+}\right]_{\mathrm{pm}}$ recording from an $\alpha$-cell identified by Pppg-mCherry expression and an adjacent $\beta$-cell identified by the cell-type-specific

FACS sorting somehow selects for the $\alpha$-cells with $\beta$-cell-like $\mathrm{Ca}^{2+}$ responses and glucose-stimulated glucagon secretion, although the $\alpha$-cells with glucose-inhibited secretion dominate within the islet. However, there is also evidence that $\mathrm{Ca}^{2+}$ signaling may differ between isolated $\alpha$-cells and those within islets [29, 53 ] and that glucagon release is controlled by factors that may override a stimulatory $\left[\mathrm{Ca}^{2+}\right]_{\mathrm{pm}}$ signal $[28,29]$. It is pertinent to
$\left[\mathrm{Ca}^{2+}\right]_{\mathrm{pm}}$ response pattern. Irrespective of the glucose concentration, the $\alpha$-cell shows irregular $\left[\mathrm{Ca}^{2+}\right]_{\mathrm{pm}}$ oscillations which are not interrupted by diazoxide. Glutamate and adrenaline increases $\left[\mathrm{Ca}^{2+}\right]_{\mathrm{pm}}$ in the $\alpha$-cell. The $\beta$-cell shows typical $\left[\mathrm{Ca}^{2+}\right]_{\mathrm{pm}}$ elevation in response to $11 \mathrm{mM}$ glucose. Representative of 7 out of $10 \alpha$-cells in five islets. $\mathbf{c}\left[\mathrm{Ca}^{2+}\right]_{\mathrm{pm}}$ recording from another $\alpha$-cell identified by Pppg-mCherry expression and an adjacent $\beta$-cell identified on the typical response pattern. The $\alpha$-cell shows $\beta$-cell-like responses with glucose-induced elevation of $\left[\mathrm{Ca}^{2+}\right]_{\mathrm{pm}}$ that was reversed by diazoxide. However, in contrast to the $\beta$-cell, the $\alpha$ cell readily responds to glutamate and adrenaline. Representative for 3 out of $10 \alpha$-cells in five islets. Scale bars, $10 \mu \mathrm{m}$

note that the dose-response relationship for glucose-regulated glucagon secretion is U-shaped with maximal inhibition at $7 \mathrm{mM}$ glucose. At higher concentrations of the sugar, inhibition is gradually diminished and secretion even stimulated [28, 41]. It remains to establish if the population of $\alpha$-cells with $\left[\mathrm{Ca}^{2+}\right]_{\mathrm{pm}}$ increase in response to glucose elevation may perhaps explain the stimulatory glucose component. We 
conclude that our labeling approach dominatingly selects for $\alpha$-cells with expected $\left[\mathrm{Ca}^{2+}\right]_{\mathrm{pm}}$ responses to glutamate and adrenaline and reveals a considerable variability in the $\alpha$-cell reactivity to glucose.

\section{$\left[\mathrm{Ca}^{2+}\right]_{\mathrm{pm}}$ signaling in mouse $\delta$-cells}

$\left[\mathrm{Ca}^{2+}\right]_{\mathrm{pm}}$ recordings in islet cells identified as $\delta$-cells by Psstcontrolled mCherry expression showed fast and irregular $\left[\mathrm{Ca}^{2+}\right]_{\mathrm{pm}}$ oscillations in the presence of $3 \mathrm{mM}$ glucose, thus reminiscent of the responses in $\alpha$-cells (Fig. 6a). The pattern was not clearly changed by elevating glucose to 7 or $11 \mathrm{mM}$. Diazoxide reduced $\left[\mathrm{Ca}^{2+}\right]_{\text {pm }}$, consistent with the involvement of $\mathrm{K}_{\text {ATP }}$ channels in $\delta$-cell electrical activity $[5,8,16]$.
Glutamate induced prompt $\left[\mathrm{Ca}^{2+}\right]_{\mathrm{pm}}$ elevation in $\delta$-cells but there was no clear effect of adrenaline. In addition to the genetically labeled $\delta$-cell, Fig. 6a shows $\left[\mathrm{Ca}^{2+}\right]_{\mathrm{pm}}$ recordings from two unlabeled cells, which based on the $\left[\mathrm{Ca}^{2+}\right]_{\mathrm{pm}}$ signaling patterns probably are $\alpha$ - and $\beta$-cells.

Another example of $\delta$-cell $\left[\mathrm{Ca}^{2+}\right]_{\mathrm{pm}}$ signaling is shown in Fig. 6 b. Apart from the mCherry-expressing $\delta$-cell, the recording includes a non-expressing $\beta$-cell. When the glucose concentration was increased from 3 to $20 \mathrm{mM}$, the $\beta$-cell shows the typical transition from silence at low glucose to $\left[\mathrm{Ca}^{2+}\right]_{\mathrm{pm}}$ elevation followed by quite regular, slow oscillations and $\left[\mathrm{Ca}^{2+}\right]_{\mathrm{pm}}$ reaches baseline within $10 \mathrm{~min}$ after restoration of glucose to $3 \mathrm{mM}$. In contrast, the $\delta$-cell is active at $3 \mathrm{mM}$ glucose with no major change after introduction of $20 \mathrm{mM}$ glucose. After
Fig. 6 Recordings of $\left[\mathrm{Ca}^{2+}\right]_{\mathrm{pm}}$ in islet cells identified by cell-typespecific promoter-controlled expression of mCherry. TIRF microscopy recordings of $\left[\mathrm{Ca}^{2+}\right]_{\mathrm{pm}}$ in cells within intact mouse islets loaded with Fluo-4. a $\left[\mathrm{Ca}^{2+}\right]_{\mathrm{pm}}$ recording from a $\delta$-cell identified by Psst-mCherry expression and adjacent $\alpha$ - and $\beta$ cells identified by typical response patterns. The $\delta$-cell shows irregular $\left[\mathrm{Ca}^{2+}\right]_{\mathrm{pm}}$ elevations already at low glucose concentrations and diazoxide lowers $\left[\mathrm{Ca}^{2+}\right]_{\mathrm{pm}}$, while glutamate induces an increase.

Representative of $8 \delta$-cells from six islets. $\mathbf{b}\left[\mathrm{Ca}^{2+}\right]_{\mathrm{pm}}$ recording from a Psst-mCherry-identified $\delta$ cell and an adjacent $\beta$-cell with typical response pattern. In the presence of high glucose, the $\beta$ cell shows regular $\left[\mathrm{Ca}^{2+}\right]_{\mathrm{pm}}$ oscillations that are synchronized with those in the $\delta$-cell. $\mathbf{c}$ $\left[\mathrm{Ca}^{2+}\right]_{\mathrm{pm}}$ recording in a PP-cell identified by Pppy-mCherry expression showing that the cell is active already at low glucose concentrations. Representative of three PP-cells from three islets. Scale bars, $10 \mu \mathrm{m}$
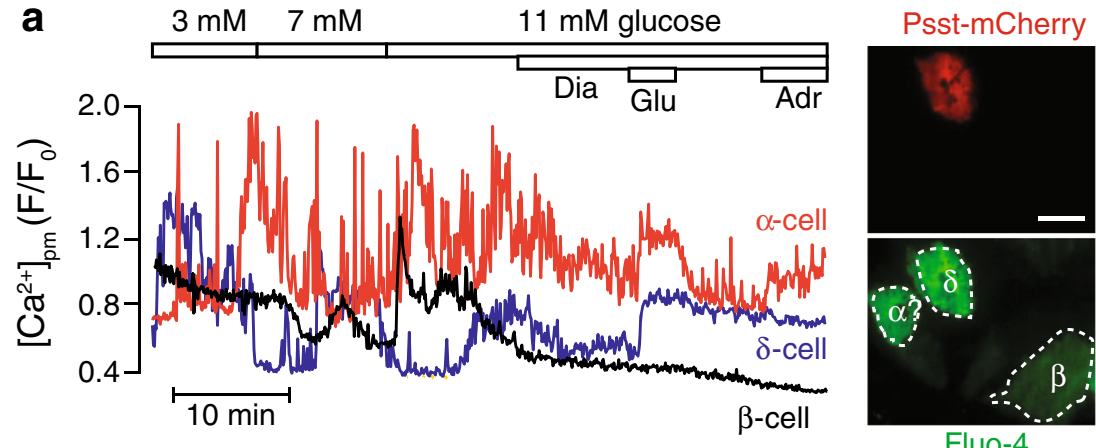

b

$20 \mathrm{mM}$ $3 \mathrm{mM}$ glucose

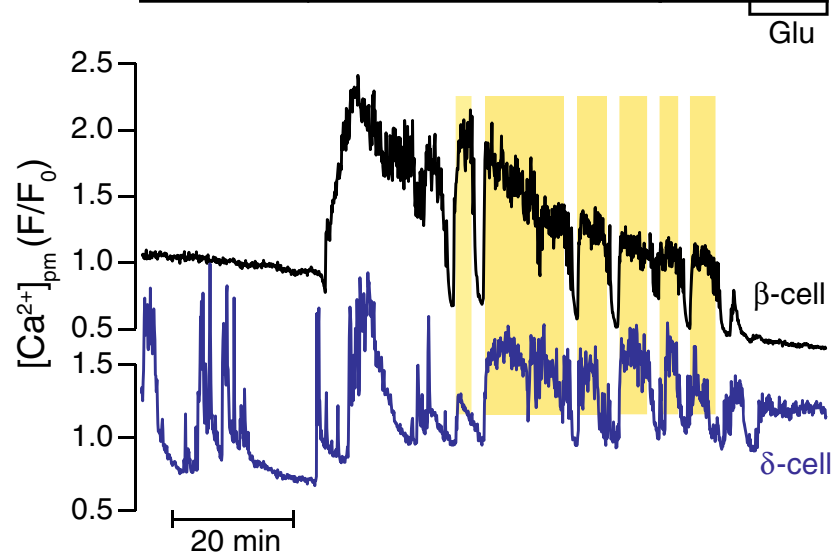

Psst-mCherry

C

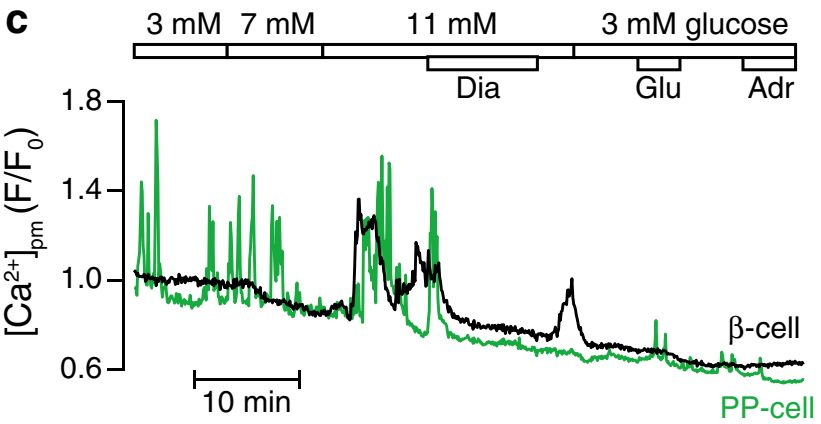

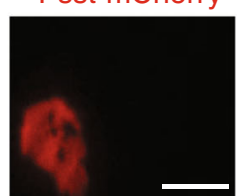

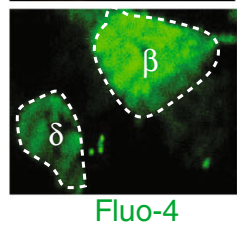

Pppy-mCherry
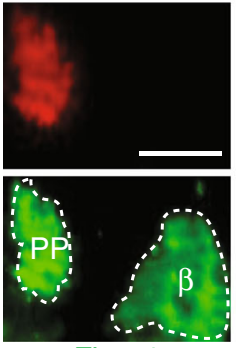

Fluo-4 
approximately $10 \mathrm{~min}$, the $\left[\mathrm{Ca}^{2+}\right]_{\mathrm{pm}}$ oscillations in the $\delta$-cell become well synchronized with those in the $\beta$-cell (Fig. 6b). The temporal relationship between $\left[\mathrm{Ca}^{2+}\right]_{\mathrm{pm}}$ oscillations in $\beta$ and $\delta$-cells within intact islets have previously not been clarified, but since pulsatile release of insulin and somatostatin is synchronized in phase [21], the prediction is that $\left[\mathrm{Ca}^{2+}\right]_{\mathrm{pm}}$ oscillations are synchronized in the same phase. Similar synchronization was recently found also between $\beta$ - and $\alpha$-cells, although insulin and glucagon pulses are synchronized in opposite phase [29]. This apparent paradox may be explained by release of somatostatin that suppresses glucagon secretion with little influence on $\alpha$-cell $\left[\mathrm{Ca}^{2+}\right]_{\mathrm{pm}}$.

\section{$\left[\mathrm{Ca}^{2+}\right]_{\mathrm{pm}}$ signaling in identified PP-cells}

PP-cells identified by Pppy-mediated expression of mCherry were also amenable for $\left[\mathrm{Ca}^{2+}\right]_{\mathrm{pm}}$ recordings. Figure $6 \mathrm{c}$ shows an example of a PP-cell exhibiting $\left[\mathrm{Ca}^{2+}\right]_{\mathrm{pm}}$ oscillations in the presence of $3 \mathrm{mM}$ glucose, which did not change appearance when glucose is increased to 7 or $11 \mathrm{mM}$. However, diazoxide promptly interrupted the signaling. There is only a weak response to glutamate and no consistent response to adrenaline (Fig. 6c).

\section{Imaging cells co-expressing genetically encoded biosensors and an identity marker}

We next tested whether the fluorescent protein labeling strategy could be used also in cells simultaneously expressing a genetically encoded biosensor. We transduced mouse or human islets with adenovirus for Rip2-mCherry and a CFP/ YFP-based biosensor for $[\mathrm{cAMP}]_{\mathrm{pm}}[12]$. Figure $7 \mathrm{a}$ shows a $[\mathrm{cAMP}]_{\mathrm{pm}}$ recording in two $\beta$-cells during an increase of the glucose concentration from 3 to $20 \mathrm{mM}$. Both cells show an initial $[\mathrm{cAMP}]_{\mathrm{pm}}$ elevation followed by a decline and a more pronounced increased with slow oscillations that are synchronized between the two cells. Since the two cells apparently
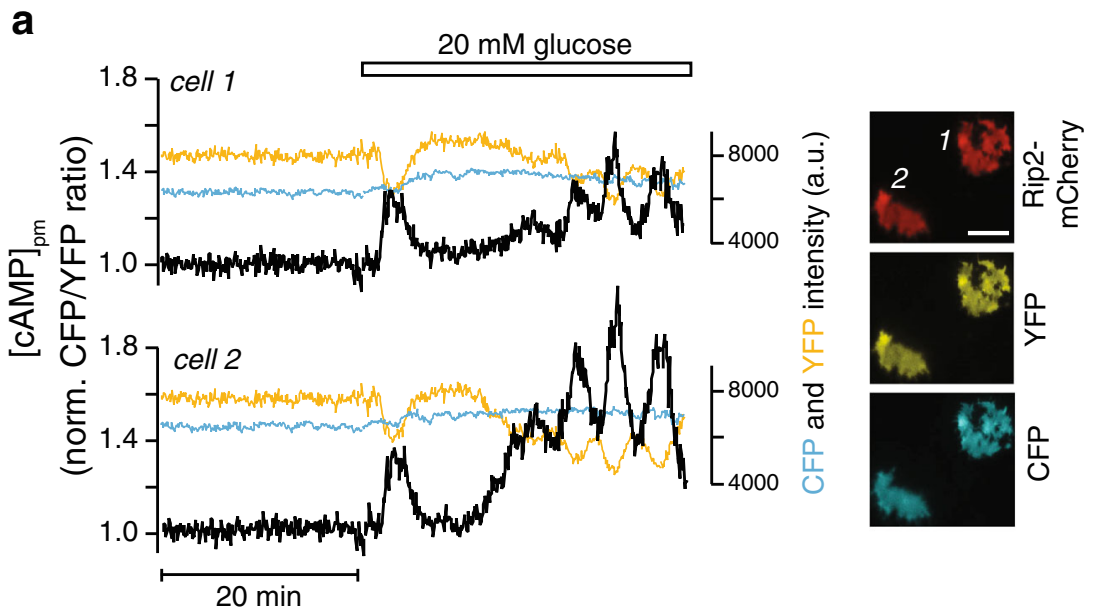

b
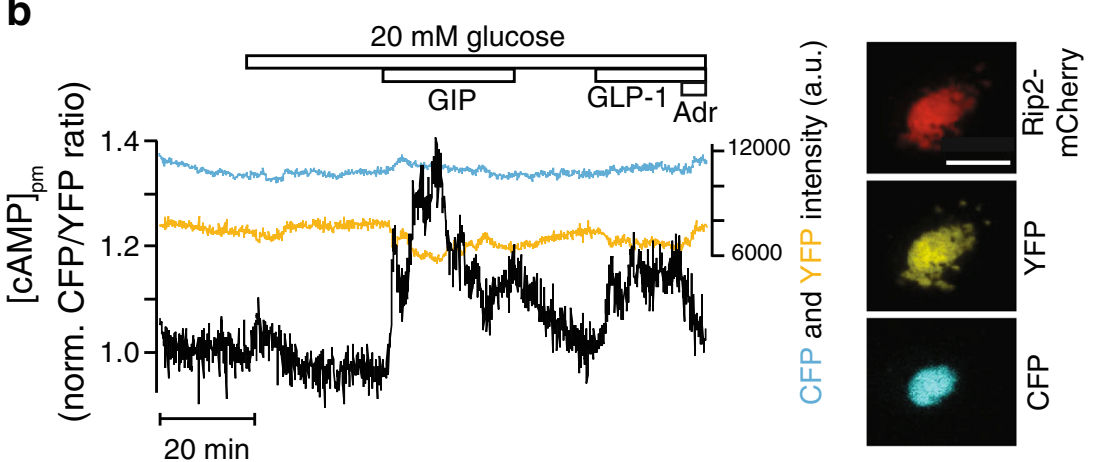

Fig. 7 Recordings of $[\mathrm{cAMP}]_{\mathrm{pm}}$ in islet $\beta$-cells identified by cell-typespecific promoter-controlled expression of mCherry. TIRF microscopy recordings of $[\mathrm{cAMP}]_{\mathrm{pm}}$ in $\beta$-cells within intact islets identified by Rip2-mCherry expression. The images show expression of Rip2mCherry and the CFP- and YFP-labeled components of the cAMP reporter. $[\mathrm{cAMP}]_{\mathrm{pm}}$ is expressed as the $\mathrm{CFP} / \mathrm{YFP}$ intensity ratio with the prestimulatory level normalized to unity (black traces). The blue and yellow traces show the CFP and YFP fluorescence intensity raw data. a $[\mathrm{cAMP}]_{\mathrm{pm}}$ recordings from two mouse $\beta$-cells in the same islet. Elevation of the glucose concentration from 3 to $20 \mathrm{mM}$ induces synchronized, oscillatory increases of $[\mathrm{cAMP}]_{\mathrm{pm}}$. Representative of 40 cells from 10 islets. $\mathbf{b}$ [cAMP $]_{\mathrm{pm}}$ recording from a human $\beta$-cell during elevation of the glucose concentration from 3 to $20 \mathrm{mM}$ followed by addition of $100 \mathrm{nM}$ GIP, $100 \mathrm{nM}$ GLP-1, and $10 \mu \mathrm{M}$ adrenaline (Adr). Representative of four cells from three islets from one donor. Scale bars, $10 \mu \mathrm{m}$ 
lack direct physical contact, the synchronization may be explained by indirect coupling due to extensive gap junctions between most $\beta$-cells within the islet [39]. We also transduced human islets with the Rip2-mCherry virus. The $\beta$-cell in Fig. $7 \mathrm{~b}$ shows a very modest $[\mathrm{cAMP}]_{\mathrm{pm}}$ elevation in response to $20 \mathrm{mM}$ glucose but pronounced [cAMP $]_{\mathrm{pm}}$ increases after stimulation with $100 \mathrm{nM}$ of the gluco-incretin hormones GIP (glucose-dependent insulinotropic polypeptide) and GLP-1 (glucagon-like peptide 1). The recording also demonstrates the $\beta$-cell typical reduction of $[\mathrm{cAMP}]_{\mathrm{pm}}$ after exposure to $10 \mu \mathrm{M}$ adrenaline (Fig. 7b).

\section{Concluding remarks}

We have created a set of viral vectors that allow pancreatic islet cell-specific expression of fluorescent proteins for their identification in various live-cell imaging applications. These vectors provide a valuable addition to the toolbox for live-cell imaging applications. In such settings, fluorescent cells are easily identified and simultaneous recordings can often be made on several cells. We first applied the tools with $\left[\mathrm{Ca}^{2+}\right]_{\mathrm{pm}}$ recordings to verify that cells responded normally to well-known stimuli and previously described functional identification criteria. These initial measurements highlighted a previously overlooked $\left[\mathrm{Ca}^{2+}\right]_{\mathrm{pm}}$ response pattern in certain $\alpha$-cells and indicated that $\left[\mathrm{Ca}^{2+}\right]_{\mathrm{pm}}$ oscillations in $\beta$-cells are synchronized with those in $\delta$-cells. We also demonstrated that the labeling strategy can be combined with genetically encoded fluorescence biosensors as exemplified by intracellular cAMP recordings. This approach is considerably more flexible than cell-type-specific expression of biosensors. The potential of this system could be further improved using an infrared fluorescent protein for identification, and leave the visual spectral channels for functional biosensors.

\begin{abstract}
Acknowledgments We thank Prof. Göran Akusjärvi, Uppsala University, for providing the pBR322-E3-Tet-On-rev plasmid and generous advice on the vector design and Mrs. Helene Dansk for skillful help with islet isolations. This study was supported by grants from the Swedish Research Council (325-2012-6778, 55X-06240), the Swedish Diabetes Foundation, Diabetes Wellness Foundation (670_2015PG), Family Ernfors Foundation, European Foundation for the Study of Diabetes/ MSD, Novo-Nordisk Foundation and the Swedish national strategic grant initiative EXODIAB (Excellence of diabetes research in Sweden). The Nordic Network for Clinical Islet transplantation supported by EXODIAB and the Juvenile Diabetes Research Foundation generously provided human islets.

Author contributions HS generated expression vectors, performed labeling and immunostaining experiments, $\left[\mathrm{Ca}^{2+}\right]_{\mathrm{pm}}$ recordings, and data analysis, and wrote the manuscript; YX designed and generated expression vectors; QY performed $\left[\mathrm{Ca}^{2+}\right]_{\mathrm{pm}}$ recordings; $\mathrm{EG}$ analyzed data and wrote the manuscript; and AT conceived the study, analyzed data, and wrote the manuscript. All authors have approved the final version of the manuscript.
\end{abstract}

Compliance with ethical standards
Ethical approval All procedures for animal handling and islet isolation were approved by the Uppsala animal ethics committee, and all experiments with human islets were approved by the Uppsala human ethics committee.

Conflict of interest The authors declare that they have no conflict of interest.

Open Access This article is distributed under the terms of the Creative Commons Attribution 4.0 International License (http:// creativecommons.org/licenses/by/4.0/), which permits unrestricted use, distribution, and reproduction in any medium, provided you give appropriate credit to the original author(s) and the source, provide a link to the Creative Commons license, and indicate if changes were made.

\section{References}

1. Adriaenssens A, Lam BY, Billing L, Skeffington K, Sewing S, Reimann F, Gribble F (2015) A transcriptome-led exploration of molecular mechanisms regulating somatostatin-producing D-cells in the gastric epithelium. Endocrinology 156:3924-3936. doi:10.1210/en.2015-1301

2. Aragon F, Karaca M, Novials A, Maldonado R, Maechler P, Rubi B (2015) Pancreatic polypeptide regulates glucagon release through PPYR1 receptors expressed in mouse and human alpha-cells. Biochim Biophys Acta 1850:343-351. doi:10.1016/j. bbagen.2014.11.005

3. Barg S, Galvanovskis J, Göpel SO, Rorsman P, Eliasson L (2000) Tight coupling between electrical activity and exocytosis in mouse glucagon-secreting $\alpha$-cells. Diabetes 49:1500-1510

4. Berenjian S, Akusjärvi G (2006) Binary AdEasy vector systems designed for Tet-ON or Tet-OFF regulated control of transgene expression. Virus Res 115:16-23. doi: 10.1016/j.virusres.2005.07.001

5. Berts A, Ball A, Dryselius G, Gylfe E, Hellman B (1996) Glucose stimulation of somatostatin-producing islet cells involves oscillatory $\mathrm{Ca}^{2+}$ signaling. Endocrinology 137:693-697. doi:10.1210 /endo.137.2.8593819

6. Berts A, Gylfe E, Hellman B (1997) Cytoplasmic $\mathrm{Ca}^{2+}$ in glucagonproducing pancreatic $\alpha$-cells exposed to carbachol and agents affecting $\mathrm{Na}^{+}$fluxes. Endocrine 6:79-83. doi:10.1007/BF02738806

7. Bramswig NC, Everett LJ, Schug J, Dorrell C, Liu C, Luo Y, Streeter PR, Naji A, Grompe M, Kaestner KH (2013) Epigenomic plasticity enables human pancreatic $\alpha$ to $\beta$ cell reprogramming. J Clin Invest 123:1275-1284. doi:10.1172/JCI66514

8. Braun M, Ramracheya R, Amisten S, Bengtsson M, Moritoh Y, Zhang Q, Johnson PR, Rorsman P (2009) Somatostatin release, electrical activity, membrane currents and exocytosis in human pancreatic delta cells. Diabetologia 52:1566-1578. doi:10.1007 /s00125-009-1382-z

9. Cabrera O, Jacques-Silva MC, Speier S, Yang SN, Kohler M, Fachado A, Vieira E, Zierath JR, Kibbey R, Berman DM, Kenyon NS, Ricordi C, Caicedo A, Berggren PO (2008) Glutamate is a positive autocrine signal for glucagon release. Cell Metab 7:545-554. doi:10.1016/j.cmet.2008.03.004

10. Chow RH, Lund PE, Löser S, Panten U, Gylfe E (1995) Coincidence of early glucose-induced depolarization with lowering of cytoplasmic $\mathrm{Ca}^{2+}$ in mouse pancreatic $\beta$-cells. J Physiol 485(Pt 3):607-617

11. Drucker DJ, Philippe J, Jepeal L, Habener JF (1987) Glucagon gene 5 '-flanking sequences promote islet cell-specific gene transcription. J Biol Chem 262:15659-15665

12. Dyachok O, Idevall-Hagren O, Sågetorp J, Tian G, Wuttke A, Arrieumerlou C, Akusjärvi G, Gylfe E, Tengholm A (2008) Glucose-induced cyclic AMP oscillations regulate pulsatile insulin secretion. Cell Metab 8:26-37. doi: 10.1016/j.cmet.2008.06.003 
13. Dyachok O, Isakov Y, Sågetorp J, Tengholm A (2006) Oscillations of cyclic AMP in hormone-stimulated insulin-secreting $\beta$-cells. Nature 439:349-352

14. Gylfe E, Gilon P (2014) Glucose regulation of glucagon secretion. Diabetes Res Clin Pract 103:1-10. doi:10.1016/j.diabres.2013.11.019

15. Gylfe E, Tengholm A (2014) Neurotransmitter control of islet hormone pulsatility. Diabetes, Obesity and Metabolism 16(Suppl 1): $102-110$

16. Göpel SO, Kanno T, Barg S, Rorsman P (2000) Patch-clamp characterisation of somatostatin-secreting $\delta$-cells in intact mouse pancreatic islets. J Physiol 528:497-507

17. Hara M, Wang X, Kawamura T, Bindokas VP, Dizon RF, Alcoser SY, Magnuson MA, Bell GI (2003) Transgenic mice with green fluorescent protein-labeled pancreatic $\beta$-cells. Am J Physiol Endocrinol Metab 284:E177-E183. doi:10.1152/ajpendo.00321.2002

18. Hauge-Evans AC, King AJ, Carmignac D, Richardson CC, Robinson IC, Low MJ, Christie MR, Persaud SJ, Jones PM (2009) Somatostatin secreted by islet $\delta$-cells fulfills multiple roles as a paracrine regulator of islet function. Diabetes 58:403-411. doi: $10.2337 / \mathrm{db} 08-0792$

19. Hellman B, Gylfe E, Bergsten P, Grapengiesser E, Berts A, Liu YJ, Tengholm A, Westerlund J (1997) Oscillatory signaling and insulin release in human pancreatic $\beta$-cells exposed to strontium. Endocrinology 138:3161-3165. doi:10.1210/endo.138.8.5296

20. Hellman B, Salehi A, Grapengiesser E, Gylfe E (2012) Isolated mouse islets respond to glucose with an initial peak of glucagon release followed by pulses of insulin and somatostatin in antisynchrony with glucagon. Biochem Biophys Res Commun 417:1219-1223. doi:10.1016/j.bbrc.2011.12.113

21. Hellman B, Salehi A, Gylfe E, Dansk H, Grapengiesser E (2009) Glucose generates coincident insulin and somatostatin pulses and antisynchronous glucagon pulses from human pancreatic islets. Endocrinology 150:5334-5340. doi:10.1210/en.2009-0600

22. Herrera PL, Huarte J, Zufferey R, Nichols A, Mermillod B, Philippe J, Muniesa P, Sanvito F, Orci L, Vassalli JD (1994) Ablation of islet endocrine cells by targeted expression of hormone-promoter-driven toxigenes. Proc Natl Acad Sci U S A 91:12999-13003

23. Hutchens T, Piston DW (2015) EphA4 receptor forward signaling inhibits glucagon secretion from $\alpha$-cells. Diabetes 64:3839-3851. doi:10.2337/db15-0488

24. Jaspan JB, Lever E, Polonsky KS, Van Cauter E (1986) In vivo pulsatility of pancreatic islet peptides. Am J Phys 251:E215-E226

25. Jin $\mathrm{T}$ (2008) Mechanisms underlying proglucagon gene expression. J Endocrinol 198:17-28. doi:10.1677/joe-08-0085

26. Kanno T, Göpel SO, Rorsman P, Wakui M (2002) Cellular function in multicellular system for hormone-secretion: electrophysiological aspect of studies on $\alpha$-, $\beta$ - and $\delta$-cells of the pancreatic islet. Neurosci Res 42:79-90

27. Lang DA, Matthews DR, Burnett M, Turner RC (1981) Brief, irregular oscillations of basal plasma insulin and glucose concentrations in diabetic man. Diabetes 30:435-439

28. Le Marchand SJ, Piston DW (2010) Glucose suppression of glucagon secretion: metabolic and calcium responses from $\alpha$-cells in intact mouse pancreatic islets. J Biol Chem 285:14389-14398. doi:10.1074/jbc.M109.069195

29. Li J, Yu Q, Ahooghalandari P, Gribble FM, Reimann F, Tengholm A, Gylfe E (2015) Submembrane ATP and $\mathrm{Ca}^{2+}$ kinetics in $\alpha$-cells: unexpected signaling for glucagon secretion. FASEB J 29:33793388. doi:10.1096/fj.14-265918

30. Liu YJ, Hellman B, Gylfe E (1999) $\mathrm{Ca}^{2+}$ signaling in mouse pancreatic polypeptide cells. Endocrinology 140:5524-5529. doi:10.1210/endo.140.12.7198

31. Liu YJ, Vieira E, Gylfe E (2004) A store-operated mechanism determines the activity of the electrically excitable glucagon-secreting pancreatic $\alpha$-cell. Cell Calcium 35:357-365. doi:10.1016/j. ceca.2003.10.002
32. Loew R, Heinz N, Hampf M, Bujard H, Gossen M (2010) Improved Tet-responsive promoters with minimized background expression. BMC Biotechnol 10:81. doi:10.1186/1472-6750-10-81

33. Nian M, Drucker DJ, Irwin D (1999) Divergent regulation of human and rat proglucagon gene promoters in vivo. Am J Phys 277: G829-G837

34. O'Rahilly S, Turner RC, Matthews DR (1988) Impaired pulsatile secretion of insulin in relatives of patients with non-insulindependent diabetes. N Engl J Med 318:1225-1230. doi:10.1056 /nejm198805123181902

35. Olsen HL, Theander S, Bokvist K, Buschard K, Wollheim CB, Gromada J (2005) Glucose stimulates glucagon release in single rat $\alpha$-cells by mechanisms that mirror the stimulus-secretion coupling in $\beta$-cells. Endocrinology 146:4861-4870. doi: 10.1210 /en.2005-0800

36. Orci L (1982) Macro- and micro-domains in the endocrine pancreas. Diabetes 31:538-565

37. Pørksen N (2002) The in vivo regulation of pulsatile insulin secretion. Diabetologia 45:3-20

38. Quoix N, Cheng-Xue R, Guiot Y, Herrera PL, Henquin JC, Gilon P (2007) The GluCre-ROSA26EYFP mouse: a new model for easy identification of living pancreatic $\alpha$-cells. FEBS Lett 581:42354240. doi:10.1016/j.febslet.2007.07.068

39. Ravier MA, Guldenagel M, Charollais A, Gjinovci A, Caille D, Sohl G, Wollheim CB, Willecke K, Henquin JC, Meda P (2005) Loss of connexin 36 channels alters $\beta$-cell coupling, islet synchronization of glucose-induced $\mathrm{Ca}^{2+}$ and insulin oscillations, and basal insulin release. Diabetes 54:1798-1807

40. Rohrer S, Menge BA, Gruber L, Deacon CF, Schmidt WE, Veldhuis JD, Holst JJ, Meier JJ (2012) Impaired crosstalk between pulsatile insulin and glucagon secretion in prediabetic individuals. J Clin Endocrinol Metab 97:E791-E795. doi:10.1210/jc.2011-3439

41. Salehi A, Vieira E, Gylfe E (2006) Paradoxical stimulation of glucagon secretion by high glucose concentrations. Diabetes 55:2318 2323. doi: $10.2337 / \mathrm{db} 06-0080$

42. Satin LS, Butler PC, Ha J, Sherman AS (2015) Pulsatile insulin secretion, impaired glucose tolerance and type 2 diabetes. Mol Asp Med 42:61-77. doi:10.1016/j.mam.2015.01.003

43. Schuit FC, Derde MP, Pipeleers DG (1989) Sensitivity of rat pancreatic A and B cells to somatostatin. Diabetologia 32:207-212

44. Schuit FC, Pipeleers DG (1986) Differences in adrenergic recognition by pancreatic A and B cells. Science (New York, NY) 232: 875-877

45. Steiner DJ, Kim A, Miller K, Hara M (2010) Pancreatic islet plasticity: interspecies comparison of islet architecture and composition. Islets 2:135-145

46. Tan W, Janczewski WA, Yang P, Shao XM, Callaway EM, Feldman JL (2008) Silencing preBotzinger complex somatostatin-expressing neurons induces persistent apnea in awake rat. Nat Neurosci 11: 538-540. doi: $10.1038 / \mathrm{nn} .2104$

47. Tan W, Pagliardini S, Yang P, Janczewski WA, Feldman JL (2010) Projections of preBotzinger complex neurons in adult rats. J Comp Neurol 518:1862-1878. doi:10.1002/cne.22308

48. Thorel F, Nepote V, Avril I, Kohno K, Desgraz R, Chera S, Herrera PL (2010) Conversion of adult pancreatic $\alpha$-cells to $\beta$-cells after extreme $\beta$-cell loss. Nature 464:1149-1154. doi:10.1038 /nature08894

49. Tian G, Sandler S, Gylfe E, Tengholm A (2011) Glucose- and hormone-induced cAMP oscillations in $\alpha$ - and $\beta$-cells within intact pancreatic islets. Diabetes 60:1535-1543. doi:10.2337/db10-1087

50. Unger RH (1985) Glucagon physiology and pathophysiology in the light of new advances. Diabetologia 28:574-578

51. van der Meulen T, Huising MO (2015) Role of transcription factors in the transdifferentiation of pancreatic islet cells. J Mol Endocrinol 54:R103-R117. doi:10.1530/JME-14-0290 
52. Vieira E, Liu YJ, Gylfe E (2004) Involvement of $\alpha 1$ and $\beta$ adrenoceptors in adrenaline stimulation of the glucagon-secreting mouse $\alpha$-cell. Naunyn Schmiedeberg's Arch Pharmacol 369:179183. doi:10.1007/s00210-003-0858-5

53. Vieira E, Salehi A, Gylfe E (2007) Glucose inhibits glucagon secretion by a direct effect on mouse pancreatic alpha cells. Diabetologia 50:370-379

54. Wierup N, Svensson H, Mulder H, Sundler F (2002) The ghrelin cell: a novel developmentally regulated islet cell in the human pancreas. Regul Pept 107:63-69
55. Yonekura H, Nata K, Watanabe T, Kurashina Y, Yamamoto H, Okamoto H (1988) Mosaic evolution of prepropancreatic polypeptide. II. Structural conservation and divergence in pancreatic polypeptide gene. J Biol Chem 263:2990-2997

56. Zhou X, Vink M, Klaver B, Berkhout B, Das AT (2006) Optimization of the Tet-On system for regulated gene expression through viral evolution. Gene Ther 13:1382-1390. doi:10.1038/sj. gt.3302780 